\title{
PENGARUH ABSENSI FINGERPRINT TERHADAP DISIPLIN KERJA KARYAWAN PADA PT. SANBIO LABORATORIES GUNUNG PUTRI KABUPATEN BOGOR
}

\author{
Dodi R. Setiawan \& Yulianti \\ Institut Ilmu Sosial dan Manajemen STIAMI \\ dodi.rs2303@gmail.com
}

\begin{abstract}
Abstrak. Tujuan penelitian ini adalah untuk mengetahui bagaimana pengaruh absensi fingerprint terhadap disiplin kerja karyawan PT. Sanbio Laboratories. Penelitian ini menggunakan metode korelasi untuk melihat seberapa besar pengaruh variable bebas dan variable terikat. Populasi penelitian adalah seluruh pekerja PT. Sanbio Laboratories sebanyak 67 karyawan, sedangkan yang dijadikan sampel adalah 50\% dari populasi atau 34 responden karyawan dengan teknik sampling menggunakan Simple Random Sampling. Setiap responden diberikan sebanyak 13 pertanyaan dengan menggunakan skala likert.

Berdasarkan hasil pengolahan data menunjukkan bahwa absensi kehadiran melalui fingerprint memberikan pengaruh yang kuat terhadap disiplin kerja karyawan di PT. Sanbio Laboratories. Sebagaimana didapat rumus persamaan regresi linier sederhana dari hasil pengolahan data, yaitu $Y$ $=1.10+0.75 \mathrm{X}$. Besarnya koefisien regresi adalah 0,75 yang menyatakan bahwa jika absensi fingerprint bertambah sebesar 1 poin, maka disiplin kerja karyawan akan mengalami perubahan Y sebesar 0,75 .
\end{abstract}

Kata Kunci: kedisplinan kerja, kedisiplinan karyawan, absensi karyawan

Abstract. The purpose of this research to know how much inflluence on the discipline of employee fingerprint attendance on employee work discipline in PT. Sanbio Laboratories. This study uses correlation to see how big the influence of independent variables and the dependent variable. The population of this study were all employees of PT. Sanbio Laboratories is 67 people, and that is sampled is $50 \%$ of all employees of PT. Sanbio Laboratories that is 34 people, with a sampling technique uses Simple Random Sampling. Each respondent was given 13 questions using a Likert scale.

The results of data processing show that the influence of discipline of fingerprint attendance on employees at PT. Sanbio Laboratories in Gunung Putri is Strong. As evidenced by a simple regression analysis that can be $Y=1.10+0.75 x$, meaning that each increase in score of 1 , it will cause a change in the variable $Y$ with a value of 0.75. This shows that the better attendance then increasing employee discipline.

Keywords: work discipline, employee discipline, workers attendance

Perkembangan ilmu pengetahuan disegala bidang saat ini begitu pesat, terutama dalam bidang Teknologi Informasi (TI) seiring dengan kebutuhan organisasi untuk memfasilitas segala aktivitasnya dalam rangka mencapai tujuan. Salah satu contohnya adalah perkembangan aplikasi komputer untuk memenuhi setiap jenis aktivitas yang ada dalam organisasi, sehingga memudahkan bagi setiap karyawan dalam melaksanakan tugas dan tanggung jawabnya.
Penggunaan komputer dalam suatu sistem informasi yang dibangun organisasi tidak lepas dari penyediaan aplikasi berupa software dan hardware yang memiliki kecepatan proses yang memadai sebanding dengan beban dan tuntutan pekerjaan, setara dengan penyediaan brainware, sehingga user yang menjalankan sistem tersebut merasa lebih mudah, cepat serta akurat dan masal.

Peranan teknologi informasi terhadap kemajuan suatu perusahaan sudah tidak 
Dodi R. Setiawan \& Yulianti, Pengaruh Absensi Fingerprint Terhadap Disiplin Kerja Karyawan...

diragukan lagi, dengan dukungan teknologi informasi yang baik maka sebuah perusahaan akan memiliki berbagai keunggulan kempetitif untuk mampu bersaing dengan perusahaan lain. Oleh karena itu, sebagian besar perusahaan berani mengadop dan menerapkan berbagai teknologi informasi berupa pengadaan sistem komputerisasi. PT. Sanbio Laboratories adalah salah satu dari sekian banyak perusahaan yang menggunakan dan memanfaatkan teknologi informasi dalam kegiatan operasionalnya.

PT. Sanbio Laboratories adalah perusahaan yang bergerak dibidang farmasi dengan memproduksi vaksin untuk hewan ternak. Sudah cukup lama PT. Sanbio Laboratories menggunakan software absensi model fingerprint untuk mengetahui dan mengontrol disiplin para karyawannya. Fingerprint adalah mesin absensi yang menggunakan sidik jari sebagai material kontrol pada masing-masing karyawan, dimana sidik jari tiap-tiap orang tidak ada yang sama. Fingerprint merupakan sistim cek kehadiran karyawan yang cukup modern untuk merekam jam masuk dan jam pulang karyawan. Dengan sistim ini, karyawan tidak bisa lagi menitip cek kehadiran kepada pihak lain, karena alat ini hanya bisa merekam sidik jari karyawan yang bersangkutan. Oleh karena itu, dengan mesin tersebut kehadiran setiap karyawan tidak dapat dimanipulasi dan jauh lebih mudah dalam penggunaanya dibandingkan dengan teknologi lainnya.

Efisiensi juga menjadi dasar pertimbangan dalam penggunaan absensi fingerprint pada PT. Sanbio Laboratories. Bagi PT. Sanbio Laboratories, alat ini sangat membantu perusahaan dalam rangka menghemat waktu, tenaga, sekaligus menjamin keamanan dan kemudahan, khususnya divisi SDM dalam mencatat, merekap serta melaporkan serta mengevaluasi tingkat disiplin karyawan.

Penggunaan sistem absensi dengan fingerprint dapat menghindarkan kecurangankecurangan absensi, misalnya: manifulasi kehadiran dengan menitip absent pada pihak lain, korupsi waktu, tidak akan kehilangan alat absensi, waktu tidak dapat diset atau reset manual oleh karyawan. Sehingga data kehadiran hasil dari sistem ini, semestinya lebih akurat dalam menggambarkan kehadiran dan kepulangan karyawan, lebih cepat karena otomatis langsung terrekam dalam database, serta mudah dalam mengoperasikannya.

Disiplin kerja merupakan kesadaran karyawan untuk mentaati aturan-aturan yang telah ditetapkan dan disepakati bersama dalam suatu perusahaan. Bila setiap karyawan mentaati aturan-aturan perusahaan seperti misalnya job desc dan SOP, maka produktivitas kerja yang tinggi akan tercapai. Sehingga dapat dikatakan bahwa disiplin kerja merupakan salah satu faktor yang penting bagi keberhasilan dan kemajuan perusahaan.

Berdasarkan fenomena berikut hasil pengamatan yang ada ditemukan, bahwa masih ada sebagian pegawai PT. Sanbio Laboratories yang tetap melakukan pelanggaran terhadap peraturan disiplin perusahaan, seperti datang terlambat dan pulang cepat, masih ada pegawai yang bolos kerja, padahal PT. Sanbio Laboratories telah menerapkan sistim absensi fingerprint.

Untuk dapat menghadapi tantangan yang dihadapi manajemen PT. Sanbio Laboratories tersebut, maka diperlukan upaya untuk mengukur dan melihat pengaruh sistem absensi kehadiran karyawan melalui fingerprint selama ini dalam menegakkan tingkat kedisiplinan kerja para karyawan yang ada di PT. Sanbio Laboratories.

\section{Perumusan Masalah}

Seberapa besar pengaruh absensi fingerprint terhadap disiplin kerja karyawan pada PT. Sanbio Laboratories di Gunung Putri Kabupaten Bogor?

\section{Manfaat Penelitian}

Penelitian ini diharapkan dapat memberi sumbangan pemikiran bagi manajemen PT. Sanbio Laboratories untuk memperkuat efektivitas sistem absensi kehadiran karyawan melalui fingerprint. Penelitian ini diharapkan dapat dijadikan bahan evaluasi untuk melihat tingkat kedisiplinan kerja para karyawan yang ada di PT. Sanbio Laboratories, Gunung Putri Kabupaten Bogor.

\section{KAJIAN LITERATUR}




\section{ISSN 1411-0830}

\section{Manajemen Sumber Daya Manusia}

Manajemen sumber daya manusia, disingkat MSDM, adalah suatu ilmu atau cara bagaimana mengatur hubungan dan peranan sumber daya (tenaga kerja) yang dimiliki oleh individu secara efisien dan efektif serta dapat digunakan secara maksimal sehingga tercapai tujuan (goal) bersama perusahaan, karyawan dan masyarakat menjadi maksimal. MSDM didasari pada suatu konsep bahwa setiap karyawan adalah manusia - bukan mesin - dan bukan semata menjadi sumber daya bisnis. Kajian MSDM menggabungkan beberapa bidang ilmu seperti psikologi, sosiologi, dan lain-lain.

Simamora (2006) mengatakan, MSDM adalah sebagai pendayagunaan, pengembangan, penilaian, pemberian balasan jasa dan pengelolaan terhadap individu anggota organisasi atau kelompok bekerja. MSDM juga menyangkut desain dan implementasi sistem perencanaan, penyusunan personalia, pengembangan karyawan, pengeloaan karir, evaluasi kerja, kompensasi karyawan dan hubungan perburuhan yang mulus. Arifin dan A. Fauzi (2007:8) berpendapat bahwa, "manajemen sumber daya manusia adalah bagian dari ilmu manajemen yang secara khusus mengatur aspek manusianya".

Pandangan lain dikemukakan Hasibuan (2006), bahwa manajemen sumber daya manusia adalah ilmu dan seni mengatur hubungan dan peranan tenaga kerja agar efektif dan efisien membantu terwujudnya tujuan perusahaan, karyawan, dan masyarakat. Sedangkan menurut Tulus dalam Suharyanto dan Hadna (2005:13), "manajemen sumber daya manusia adalah perencanaan, pengorganisasian, pengarahan, dan pengawasan atas pengadaan, pengembangan, pemberian kompensasi, pengintegrasian, pemeliharaan dan pemutusan hubungan tenaga kerja dimaksud membantu tujuan organisasi, individu dan masyarakat".

Berdasarkan tersebut dari para ahli di atas, maka dapat disimpulkan bahwa Manajemen Sumber Daya Manusia (MSDM) merupakan faktor sangat penting dalam bagaimana organisasi atau perusahaan mengelola aset sumber daya manusia secara tepat agar dapat berjalan sesuai dengan tujuan organisasi. Fungsi bidang MSDM memastikan bahwa setiap posisi jabatan diisi oleh karyawan yang kompeten, dimana setiap karyawan memahami tupoksinya masing-masing serta mampu dilaksanakan dengan baik guna mencapai tujuan organisasi.

Peranan MSDM adalah mencakup semua fungsi manajemen dan juga fungsi operasional menurut Hani Handoko (2001), yaitu:

1. Fungsi Manajerial yang mencakup, a) Perencanaan (planning), b)

Pengorganisasian (organizing), c)

Pengarahan (directing) dan, d)

Pengendalian (controlling)

2. Fungsi Operasional yang mencakup, a) Pengadaan Tenaga Kerja (procurement), yaitu suatu kegiatan yang mengkondisikan karyawan sesuai dengan kebutuhan perusahaan. Hal-hal yang dilakukan dalam kaitan ini adalah penentuan sumber daya manusia yang dibutuhkan dalam tahap perekrutan, seleksi dan penempatan, b) Pengembangan (development), yaitu kegitan yang dilakukan untuk memberikan pembekalan jabatan berupa berbagai pengetahuan dan aspek-aspek manajerial yang mendukung untuk menduduki jabatan baru yang lebih tinggi. Ini merupakan suatu kegiatan penting dan terus tumbuh karena adanya perubahan-perubahan teknologi, reorganisasi, pekerjaan, tugas manajemen, c) Kompensasi (compensation), yaitu merupakan pemberian penghargaan langsung maupun tidak langsung, financial maupun non-financial yang adil dan layak kepada karyawan atas jasa mereka dalam pencapaian tujuan organisasi. Pemberian kompensasi harus logis, rasional dan memiliki ketahanan karena kompensasi sangat rentan hubungannya dengan prestasi kerja, kepuasan kerja, dan motivasi, d) Integrasi (integration), adalah memanfaatkan karyawan agar mereka bersedia bekerja dan berpartisipasi aktif dalam menunjang tercapainya tujuan organisasi serta terpenuhinya kebutuhankebutuhan karyawan. Yang menjadi prinsip integrasi adalah mengkondisikan kerja sama 
Dodi R. Setiawan \& Yulianti, Pengaruh Absensi Fingerprint Terhadap Disiplin Kerja Karyawan...

yang baik dan saling menguntungkan, agar terbina suatu kecocokan yang layak atas kepentingan-kepentingan individu, masyarakat, dan organisasi, e) Pemeliharaan (maintenance), yaitu usaha mempertahankan dan meningkatkan kondisi fisik, mental, dan sikap karyawan agar mereka tetap loyal dan bekerja produktif agar dapat menunjang tujuan perusahaan. Untuk itu maka fungsi pemeliharaan mutlak mendapat perhatian dari manajer, f) Pemberhentian (separation), adalah pemutusan hubungan kerja seorang karyawan dengan sebuah organisasi / perusahaan dimana karyawan merupakan bagian dari organisasi tersebut. Dengan pemberhentian ini maka berarti berakhirnya hubungan kerja sama pekerjaan antara karyawan dengan perusahaan. Maksud dari semua kegiatan diatas baik fungsi manajerial maupun operasional adalah untuk membantu dalam menjelaskan sasaran tujuan dasar.

Sedangkan peran MSDM menurut Hasibuan (2006) adalah mengatur dan menetapkan program-program kepegawaian yang meliputi hal-hal berikut:

1. Menetapkan jumlah, kualitas dan penempatan tenaga kerja yang sesuai dengan kebutuhan perusahaan.

2. Melakukan rekruitmen karyawan, seleksi dan penempatan pegawai sesuai kualifikasi pegawai yang dibutuhkan perusahaan.

3. Menetapkan program kesejahteraan, pengembangan, promosi dan pemutusan hubungan kerja.

4. Membuat perkiraan kebutuhan pegawai dimasa yang akan datang.

5. Memperkirakan kondisi ekonomi pada umumnya dan perkembangan perusahaan pada khususnya.

6. Senantiasa memantau perkembangan undang-undang ketenagakerjaan dari waktu ke waktu khususnya yang berkaitan dengan gaji/upah atau kompensasi terhadap pegawai.

7. Memberikan kesempatan karyawan dalam hal pendidikan, pelatihan dan penilaian prestasi kerja karyawan.

8. Mengatur mutasi kerja karyawan.
9. Mengatur pensiun, pemutusan hubungan kerja beserta perhitungan pesangon yang menjadi hak karyawan.

\section{Disiplin \& Disiplin Kerja}

Simamora (2006 : 610) menyatakan bahwa, "Disiplin adalah prosedur yang mengoreksi atau menghukum bawahan karena melanggar peraturan atau prosedur. Disiplin merupakan bentuk pengendalian diri karyawan dan pelaksanaan yang teratur serta menunjukkan tingkat kesungguhan tim kerja didalam suatu organisasi”. Pendapat lain dari Hasibuan (2006) yang menyatakan tentang Disiplin sebagai fungsi operatif MSDM yang terpenting, karena semakin baik disiplin karyawan semakin tinggi prestasi kerja yang dapat dicapainya. Tanda disiplin karyawan baik, sulit bagi organisasi perusahaan mencapai hasil yang optimal.

Adapun Disliplin kerja merupakan salah satu faktor yang dapat memberikan pengaruh terhadap pencapaian tujuan organsiasi. Definisi dari para ahli tentang Disiplin Kerja dikemukakan Hasibuan (2006: 444), bahwa "Disiplin kerja adalah kesadaran dan kerelaan seseorang dalam menaati semua peraturan perusahaan dan norma-norma sosial yang berlaku.”. Arifin dan A. Fauzi (2007:11) mengatakan, disiplin kerja adalah keinginan dan kesadaran untuk mentaati peraturanperaturan perusahaan dan norma-norma sosial yang berlaku.

Hal ini sejalan dengan pendapat Siagian (2011:230), bahwa bentuk disiplin yang baik akan tercermin pada suasana:

1. Tingginya rasa kepedulian karyawan terhadap pencapaian tujuan perusahaan.

2. Tingginya semangat dan gairah kerja dan inisiatif para karyawan dalam melakukan pekerjaan.

3. Besarnya rasa tanggung jawab para karyawan untuk melaksanakan tugas dengan sebaik baiknya.

4. Berkembangnya rasa memiliki dan rasa solidaritas yang tinggi dikalangan karyawan.

5. Meningkatnya efisiensi dan produktivitas kerja para karyawan.

Dari beberapa pengertian disiplin dan disiplin kerja yang dikemukakan oleh 


\section{ISSN 1411-0830}

beberapa ahli di atas dapat disimpulkan bahwa Disiplin menunjukkan suatu kondisi kondusif yang ada pada diri karyawan untuk bersedia taat, patuh dan hormat mengikuti peraturan yang berlaku di organisasi atau perusahaan tempat karyawan bekerja. Sedangkan Disiplin Kerja adalah sikap mental dan kesediaan karyawan secara sadar untuk mau dan mampu mematuhi segala peraturan kerja yang berlaku.

Hasibuan (2006:194) juga menyebutkan tentang aspek-aspek yang mempengaruhi disiplin kerja karyawan suatu organisasi, diantaranya adalah sebagai berikut.

1. Tujuan dan Kemampuan. Tujuan dan kemampuan ikut mempengaruhi tingkat kedisiplinan karyawan. Tujuan yang akan dicapai harus jelas dan ditetapkan secara ideal serta cukup menantang bagi kemampuan karyawan.

2. Teladan Pimpinan.Teladan pimpinan sangat berperan dalam menentukan kedisiplinan karyawan karena pimpinan dijadikan teladan dan panutan oleh bawahannya.

3. Balas Jasa. Balas jasa (gaji dan kesejahteraan) ikut mempengaruhi disiplin karyawan karena balas jasa akan memberikan kepuasan dan kecintaan karyawan terhadap perusahaan/pekerjaanya.

4. Keadilan. Keadilan ikut mendorong terwujudnya kedisiplinan karyawan, karena ego dan sifat manusia yang selalu merasa dirinya penting dan minta diperlakukan sama dengan manusia yang lainnya.

5. Waskat. Waskat ialah tindakan nyata dan efektif untuk mencegah/mengetahui kesalahan, membetulkan bawahan, menggali sistem-sistem kerja yang paling efektif, serta menciptakan simstem internal control yang terbaik dalam mendukung terwujudnya tujuan perusahaan, karyawan dan masyarakat.

6. Sanksi Hukuman. Dengan sanksi hukuman yang semakin berat, karyawan akan semakin takut melanggar peraturanperaturan perusahaan, sikap dan perilaku indisipliner karyawan akan berkurang.
Berat ringannya sanksi hukuman akan diterapkan ikut mempengaruhi baik/buruknya kedisiplinan karyawan. Sanksi hukuman harus dipertimbangkan secara logis, masuk akal dan diinformasikan secara jelas kepada semua karyawan. Sanksi hukuman seharusnya tidak terlalu ringan, namun juga tidak terlalu berat agar dapat tetap mendidik karyawan untuk mengubah perilakunya.

Adapun Indikator disiplin Kerja menurut Singodimejo dalam Sutrisno (2011:94) adalah sebagai berikut:

1. Taat terhadap aturan waktu. Dilihat dari jam masuk kerja, jam pulang, dan jam istirahat yang tepat waktu sesuai dengan aturan yang berlaku di perusahaan.

2. Taat terhadap peraturan perusahaan. Peraturan dasar tentang cara berpakaian, dan bertingkah laku dalam pekerjaan.

3. Taat terhadap aturan perilaku dalam pekerjaan. Ditunjukan dengan cara-cara melakukan pekerjaan-pekerjaan sesuai dengan jabatan, tugas, dan tanggung jawab serta cara berhubungan dengan unit kerja lain.

4. Taat terhadap peraturan lainnya diperusahaan. Aturan tentang apa yang boleh dan apa yang tidak boleh dilakukan oleh para pegawai dalam perusahaan.

Sementara indikator menurut Hasibuan (2010) adalah sebagai berikut:

1. Mematuhi semua peraturan perusahaan

2. Penggunaan waktu secara efektif

3. Tanggung jawab dalam pekerjaan dan tugas

4. Tingkat absensi

Lain halnya indikator disiplin menurut Geroge Straves dan Leonard Sayles yang dikutip oleh Hadikusuma \& Rochmulyati (2000:98) adalah sebagai berikut:

1. Presensi (Kehadiran)

2. Penggunaan Jam Kerja

3. Tanggung Jawab

4. Tingkat Perputaran Pegawai

\section{Absensi Fingerprint}


Dodi R. Setiawan \& Yulianti, Pengaruh Absensi Fingerprint Terhadap Disiplin Kerja Karyawan...

Absensi adalah sebuah kegiatan pengambilan data guna mengetahui jumlah kehadiran pada suatu acara. Dan perusahaan menggunakan sistem absensi untuk mengetahui kehadiran dan ketidakhadiran karyawan.

Salah satu sistem absensi yang banyak digunakan di perusahaan adalah sistem absensi fingerprint atau sidik jari. Sidik jari merupakan garis yang terdapat pada guratan garis jari tangan yang sering digunakan untuk keperluan pengenalan identitas seseorang. Sidik jari manusia sedemikian uniknya sehingga tidak ada seorangpun yang memiliki sidik jari yang identik dengan orang lain.

Menurut Samiaji (2008:109), metode absensi yang lebih modern adalah dengan menggunakan presensi sidik jari. Pada metode ini pegawai harus memindai jari untuk presensi. Secara otomatis mesin presensi ini memasukan data jam masuk dan pulang ke dalam komputer. Hasilnya catatan jam kerja yang akurat dan siap diolah dengan aplikasi. Presensi tidak dapat dititipkan dan memperkecil kemungkinan kesalahan.

Pendapat lain dikemukakan oleh Noersasongko \& Pulung (2010) mengenai fingerprint sebagai salahsatu bentuk biometric yang dilakukan untuk mengidentifikasi manusia. Scanner jenis ini membaca berdasarkan pola jari manusia. Terdapat tiga pola dasar sidik jari yaitu, arch, loop dan whorl. Scanner akan mengirim gambar sidik jari manusia dengan salah satu dari tiga pola tersebut untuk dianalisis oleh komputer.

Sedangkan menurut Moch. Tofik (2010:9) bahwa "fingerprint adalah teknologi yang menunjang untuk keperluan absensi, yang di dalamnya mencangkup pemasukan, penyimpanan data jam masuk dan jam pulang, serta memproses data tersebut menjadi sebuah laporan yang nantinya dapat dipergunakan untuk pengambilan kebijakan-kebijakan yang dilakukan oleh pimpinan. Alat ini dilengkapi dengan software untuk melakukan perekaman atas transaksi yang terjadi".

Mesin absensi sidik jari (fingerprint) merupakan Sistem Informasi Manajemen yang mengandung elemen-elemen fisik sebagaimana diungkapkan oleh Davis
(2005:3) bahwa unsur-unsur Sistem Informasi Manajemen adalah sebagai berikut:

1. Perangkat keras komputer, terdiri atas komputer (pusat pengolahan, unit masukan/keluaran, unit penyimpanan, file, dan peralatan penyimpanan data.

2. Database (data yang tersimpan dalam media penyimpanan komputer).

3. Prosedur, komponen fisik karena prosedur disediakan dalam bentuk fisik, seperti buku panduan dan instruksi.

4. Personalia pengoperasian, seperti operator komputer, analisis sistem pembuatan program, personalia penyimpanan data dan pimpinan sistem informasi.

\section{METODE PENELITIAN}

\section{Jenis Penelitian}

Jenis penelitian ini adalah penelitian deskriptif. Penelitian deskriptif merupakan penelitian yang dimaksudkan untuk memotret fenomena individual, situasi atau kelompok tertentu yang terjadi baru-baru ini. Adapun penelitian ini untuk melihat besarnya pengaruh variabel bebas terhadap variabel terikat. Variabel bebas yang dimaksud yaitu $\mathrm{X}$ (Absensi Fingerprint), sedangkan variabel terikat (Y) yaitu Disiplin Kerja Karyawan Pada PT. Sanbio Laboratories Di Gunung Putri Kabupaten Bogor.

\section{Tempat dan Waktu Penelitian}

Penelitian ini dilaksanakan di PT. Sanbio Laboratories, Kecamatan Gunung Putri Kabupaten Bogor yang dilakukan dari bulan ......2014 sampai dengan....... 2014.

\section{Definisi Operasional}

Disiplin merupakan faktor penting dalam upaya menciptakan sumber daya manusia yang berkualitas. Salah satu parameter yang digunakan dalam pengukuran kedisiplinan kerja karyawan yaitu kemampuan karyawan untuk masuk dan pulang kerja dengan tepat waktu. Sehingga absensi mempunyai peranan yang sangat penting sebagai sarana pendukung dalam upaya menciptakan dan 
meningkatkan disiplin kerja karyawan. Informasi yang akurat dan terperinci mengenai kehadiran seorang karyawan dapat dijadikan sebagai bahan pertimbangan dalam menentukan prestasi kerja seseorang, gaji/upah, produktivitas atau kemajuan perusahaan secara umum.

Salah satu upaya dalam meningkatkan disiplin kerja karyawan yaitu melalui penggunaan mesin absensi biometrik sidik jari (fingerprint). Mesin absensi fingerprint adalah salah satu mesin absensi jenis biometrik yang menggunakan metode pendeteksian melalui sidik jari karyawan untuk daftar kehadiran karyawan. Dengan penggunaan absensi biometrik fingerprint ini, diharapkan dapat meningkatkan disiplin kerja karyawan sehingga dapat membantu organisasi perusahaan dalam mencapai tujuannya.

Berdasarkan uraian tersebut, dapat digambarkan operasionalisasi variabel sebagaimana dalam tabel berikut ini:

Tabel 1

Operasionalisasi Variabel

\begin{tabular}{|c|c|}
\hline $\begin{array}{c}\text { VARIABEL X } \\
\text { Absensi Fingerprint }\end{array}$ & $\begin{array}{l}\text { VARIABEL Y } \\
\text { Disiplin Kerja }\end{array}$ \\
\hline $\begin{array}{l}\text { Dimensi: } \\
\text { 1. Praktis } \\
\text { 2. Akurat } \\
\text { 3. Sekuritas Tinggi }\end{array}$ & $\begin{array}{l}\text { Dimensi: } \\
\text { 1. Presensi (Kehadiran) } \\
\text { 2. Penggunaan Jam Kerja } \\
\text { 3. Tanggung Jaw ab } \\
\text { 4. Tingkat Perputaran } \\
\text { Pegaw ai } \\
\text { Sumber: } \\
\text { Grace (2000:98) }\end{array}$ \\
\hline
\end{tabular}

\section{Populasi dan Sampel}

Populasi pada penelitian ini yaitu karyawan PT. Sanbio Laboratories yang berjumlah 67 karyawan. Adapun besaran sampel dalam penelitian ini sebanyak 34 orang karyawan dengan perhitungan untuk menentukan ukuran sampel maka diambil rumus menurut Surakhmad dalam web http://a-

research.upi.edu/operator/upload/s_adp_0704 694_chapter3.pdf yang berpendapat: apabila ukuran populasi sebanyak kurang dari 100, maka pengambilan sampel sekurangkurangnya $50 \%$ dari ukuran populasi. Apabila ukuran populasi sama dengan atau lebih dari 1000, ukuran sampel diharapkan sekurangkurangnya $15 \%$ dari ukuran populasi.

\section{Teknik Analisis Data}

Teknik analisis data yang digunakan dalam penelitian ini adalah sebagai berikut:

Uji Regresi Linier Sederhana (Single Regression), dengan menggunakan rumus persamaan

$\mathrm{Y}=\mathrm{a}+\mathrm{bx}$

Keterangan:

$\mathrm{Y}=$ variabel dependen (nilai yang diprediksi)

$\mathrm{X}=$ variabel independen

$\mathrm{a}=$ konstanta (nilai $\mathrm{Y}$ apabila $\mathrm{X}=0$ )

$\mathrm{b}=$ koefisien regresi (nilai peningkatan atau penurunan) 
Dodi R. Setiawan \& Yulianti, Pengaruh Absensi Fingerprint Terhadap Disiplin Kerja Karyawan...

\section{Uji Validitas Eskternal}

Penelitian ini menggunakan uji validitas eksternal dengan rumus korelasi product moment (Arikunto, 2006:169-170). Harga $\mathrm{R}_{\mathrm{xy}}$ menunjukkan indeks korelasi antara dua variabel yang dikorelasikan untuk mengetahui: 1) ada tidaknya korelasi, 2) arah korelasi, 3) besarnya korelasi.

$$
=\frac{\mathrm{n}\left(\sum \mathrm{xy}\right)-\left(\sum \mathrm{x}\right)\left(\sum \mathrm{y}\right)}{\sqrt{\left\{\mathrm{n}\left(\sum \mathrm{x}^{2}\right)-\left(\sum \mathrm{x}\right)^{2}\right\}\left\{\left(\mathrm{n}\left(\sum \mathrm{y}^{2}\right)-\left(\sum \mathrm{y}\right)^{2}\right\}\right.}}
$$

Keterangan:

$\mathrm{R}_{\mathrm{yx}}=$ Koefisien Korelasi

$\mathrm{X}=$ Variabel bebas

$\mathrm{Y}=$ Variabel terikat

\section{Uji Koefisien Determinasi $\left(\mathbf{R}^{2}\right)$}

Koefisien determinasi $\left(\mathrm{R}^{2}\right)$ digunakan untuk mengukur seberapa besar variabelvariabel independen dapat menjelaskan variabel dependen. Koefisien ini menunjukan proporsi variabilitas total pada variabel dependen yang dijelaskan oleh model regresi. Nilai $R^{2}$ berada pada interval $0 \leq R^{2} \leq 1$.

Secara logika dapat diketahui bahwa makin baik estimasi model dalam menggambarkan data, maka makin dekat nilai $\mathrm{R}$ ke nilai 1 (satu). Nilai $\mathrm{R}^{2}$ dapat diperoleh dengan rumus :

$\mathrm{R}^{2}=(r)^{2} \times 100 \%$

Keterangan:

$\mathrm{R}^{2}=$ Koefisien Determinasi

$\mathrm{R}=$ Koefisien Korelasi

\section{Uji Signifikan Korelasi}

Untuk mengetahui kebenaran dari perhitungan koefisien korelasi di atas, diperlukan uji signifikan korelasi. Untuk menguji signifikan hubungan absensi fingerprint terhadap disiplin pegawai yang berjumlah 34 responden dari 67 karyawan PT. Sanbio Laboratories, maka diperlukan uji signifikasi perhitungan sebagai berikut:

$$
t_{h}=r \sqrt{\frac{n-2}{1-r^{2}}}
$$

Kriteria pengujiannya sebagai berikut :

a. Jika $t_{\text {hitung }}>\mathrm{t}_{\text {tabel }}$, maka Ho ditolak dan H1 diterima

b. Jika $\mathrm{t}_{\text {hitung }}<\mathrm{t}_{\text {tabel}}$, maka Ho diterima dan H1 ditolak

\section{HASIL PENELITIAN}

\section{Uji Kualitas Data}

Sebelum menguji korelasi dan regresi, terlebih dahulu diuji Validitas Eksternal dengan bantuan rumus korelasi product moment sebagai berikut :

$$
\begin{aligned}
& R \\
& =\frac{34(20525)-(936 \times 742)}{\sqrt{\{34(25898)-(876096)\}\{34(16364)-(550564)\}}} \\
& R=\frac{697850-694512}{\sqrt{4436-5812}} \\
& R=\frac{3338}{5078} \\
& R=0.66
\end{aligned}
$$

Dari perhitungan korelasi diperoleh indeks $\mathrm{R}$ $=0,66$ dengan interpretasi sebagai berikut:

1. Terdapat korelasi karena angkanya besar yaitu lansung dibelakang koma tanpa tanda ada nol-nol lagi.

2. Ada korelasi antara variabel $\mathrm{X}$ dan $\mathrm{Y}$ dengan arah positif (+).

3. Besaran korelasi termasuk indeks korelasi yang besar karena mendekati angka 1,000

\section{Rekapitulasi Indikator Absensi Fingerprint}

Berdasarkan tabel rekapitulasi indikator di bawah, diperoleh nilai rata-rata untuk variabel absensi fingerprint sebesar 3,93, artinya variabel absensi fingerprint di PT. Sanbio Laboratories sudah termasuk dalam kategori baik. 
Tabel 2

Rekapitulasi Indikator

Absensi Fingerprint

\begin{tabular}{|c|l|c|c|}
\hline NO & \multicolumn{1}{|c|}{ PERNYATAAN } & NILAI & KETERANGAN \\
\hline 1 & $\begin{array}{l}\text { Kepraktisan penggunaan absensi } \\
\text { fingerprint }\end{array}$ & 4,06 & Baik \\
\hline 2 & $\begin{array}{l}\text { Kemudahan dalam penggunaan } \\
\text { absensi fingerprint }\end{array}$ & 3,82 & Baik \\
\hline 3 & $\begin{array}{l}\text { Perekaman data kehadiran lebih } \\
\text { cepat }\end{array}$ & 3,88 & Baik \\
\hline 4 & $\begin{array}{l}\text { Ketelitian pembacaan dan } \\
\text { verifikasi jari }\end{array}$ & 4,21 & Baik \\
\hline 5 & Kesesuaian jam kerja & 3,82 & Baik \\
\hline 6 & $\begin{array}{l}\text { Kecilnya resiko data kehadiran } \\
\text { untuk dimanipulasi }\end{array}$ & 3,82 & Baik \\
\hline 7 & $\begin{array}{l}\text { Keamanan penggunaan absensi } \\
\text { fingerprint }\end{array}$ & 3,91 & ( Baik ) \\
\hline & JUMLAH $\mathbf{\Sigma}=\mathbf{2 7 , 5 3 ~ / ~ 7 = 3 , 9 3}$ & & \\
\hline
\end{tabular}

Sumber: Hasil Penelitian Diolah
Rekapitulasi Indikator Disiplin Kerja
Karyawan
Berdasarkan tabel rekapitulasi di bawah,
disiplin kerja sebesar 3,64, artinya variabel disiplin kerja di PT. Sanbio Laboratories sudah termasuk dalam kategori baik.

diperoleh nilai rata-rata untuk variabel

Tabel 3

Rekapitulasi Indikator

Disiplin Kerja Karyawan

\begin{tabular}{|c|l|c|c|}
\hline NO & \multicolumn{1}{|c|}{ PERNYATAAN } & NILAI & KETERANGAN \\
\hline 1 & Datang tepat waktu & 3,71 & Baik \\
\hline 2 & Tidak bolos kerja & 3,62 & Baik \\
\hline 3 & Efisiensi penggunaan waktu kerja & 3,71 & Baik \\
\hline 4 & $\begin{array}{l}\text { Mengerjakan pekerjaan sesuai job } \\
\text { description }\end{array}$ & 3,65 & Baik \\
\hline 5 & $\begin{array}{l}\text { Menyelesaikan pekerjaan sesuai } \\
\text { target }\end{array}$ & 3,56 & Baik \\
\hline 6 & Tingkat keluar masuk karyawan & 3,59 & ( Baik ) \\
\hline & JUMLAH $\Sigma=\mathbf{2 1 , 8 2 ~ / 6 = 3 , 6 4}$ & & \\
\hline
\end{tabular}

Sumber: Hasil Penelitian Diolah 
Dodi R. Setiawan \& Yulianti, Pengaruh Absensi Fingerprint Terhadap Disiplin Kerja Karyawan...

\section{Pengujian Kriteria Statistik}

\section{Uji Signifikansi Korelasi Pada Variabel} Bebas Absensi Fingerprint (X) Terhadap Variabel Terikat Displin Kerja Karyawan (Y)

Dari hasil uji t, dapat dilihat bahwa dengan menggunakan rumus $t_{\text {tabel }}$ dengan tingkat kesalahan 5\% $(\alpha=0.05 \%)$ uji dua pihak dengan $\mathrm{dk}=32$ yaitu $34-2=32$ sehingga diperoleh $t_{\text {tabel }}=2.00$. Dari uji signifikan korelasi product moment maka diperoleh $t_{\text {hitung }}=4.94$. Hal tersebut berarti $t_{\text {hitung }}>$ $t_{\text {tabel }}$ dapat disimpulkan bahwa hipotesis nol ditolak dan hipotesis alternatif diterima, yang artinya absensi fingerprint mempunyai hubungan yang positif dan signifikan terhadap disiplin kerja karyawan pada PT. Sanbio Laboratories.

\section{Analisis Koefisien Determinasi}

Seberapa besar kontribusi yang diberikan oleh faktor absensi fingerprint sebagai variabel bebas (X) terhadap disiplin kerja karyawan sebagai variabel terikat (Y), adalah diketahui:

$$
\begin{aligned}
\mathrm{Kd} & =r^{2} \times 100 \% \\
& =0.66^{2} \times 100 \% \\
& =43.56 \%
\end{aligned}
$$

Dilihat dari koefisien determinasi di atas, dapat diketahui bahwa tingkat keragaman sebesar 43,56 persen. Hal ini berarti bahwa disiplin kerja karyawan dipengaruhi oleh absensi fingerprint yang merupakan salah satu faktor penting dalam meningkatkan kedisiplinan pegawai, dimana sebesar 56,44 persen disiplin karyawan dipengaruhi oleh faktor-faktor lainnya yang dalam penelitian ini tidak dianalisis.

\section{Model Persamaan Regresi Sederhana Antara Absensi Fingerprint Terhadap Disiplin Kerja Karyawan}

Diperoleh nilai konstanta dan koefesien regresi sebagai berikut:

$$
\mathrm{a}=\frac{\left(\sum x^{2}\right)\left(\sum y\right)-\left(\sum x\right)\left(\sum x y\right)}{n\left(\sum x^{2}\right)-\left(\sum x\right)^{2}}
$$

$$
\begin{aligned}
& a=\frac{(25898 \times 742)-(936 \times 20525)}{34(25898)-(876096)} \\
& a=\frac{19216316-19211400}{880532-876096} \\
& a=\frac{4916}{4436} \\
& \mathbf{a}=\mathbf{1 . 1 0} \\
& b=\frac{n\left(\sum x y\right)-\left(\sum x\right)\left(\sum y\right)}{n\left(\sum x^{2}\right)-\left(\sum x\right)^{2}} \\
& b=\frac{34(20525)-(936 \times 742)}{34(25898)-(876096)} \\
& b=\frac{697850-694512}{880532-876096} \\
& b=\frac{3338}{4436} \\
& \mathbf{b}=\mathbf{0 . 7 5}
\end{aligned}
$$

Dari perhitungan rumusan di atas, maka didapatkan persamaan regresi dan pengaruh absensi fingerprint terhadap disiplin kerja adalah sebagai berikut:

$\mathrm{Y}=1.10+0.75 \mathrm{X}$

Besarnya koefisien regresi adalah 0,75 yang menyatakan bahwa setiap kenaikan/perubahan variabel X (absensi fingerprint ) sebesar skor 1 akan menyebabkan perubahan pada variabel $\mathrm{Y}$ (disiplin kerja) dengan nilai sebesar 0,75.

\section{PEMBAHASAN}

Berdasarkan pengujian hipotesis di atas, maka terdapat beberapa hal yang perlu diuraikan sehubungan dengan pemecahan masalah.

1. Absensi Fingerprint Karyawan Pada

\section{PT. Sanbio Laboratories}

Berdasarkan angka rata-rata penafsiran yang diperoleh yaitu $\boldsymbol{\Sigma}=3,93$ maka dapat dikatakan bahwa penggunaan teknologi untuk keperluan absensi melalui mesin fingerprint sudah tergolong baik namun harus ditingkatkan. Peningkatan sangat diperlukan terutama pada kemudahan dalam penggunaan absensi fingerprint, kesesuaian jam kerja 
dan tingkat kepercayaan atas resiko data kehadiran untuk dimanipulasi.

2. Disiplin Kerja Karyawan PT. Sanbio Laboratories

Berdasarkan angka rata-rata penafsiran yang diperoleh yaitu $\boldsymbol{\Sigma}=3,64$ maka dapat dikatakan bahwa tingkat kedisiplinan kerja karyawan PT. Sanbio Laboratories sudah tergolong baik namun harus ditingkatkan. Peningkatan sangat diperlukan terutama pada menyelesaikan pekerjaan sesuai target.

3. Pengaruh Absensi Fingerprint Terhadap Disiplin Kerja Karyawan PT. Sanbio Laboratories

$t_{\text {hitung }}=4.94$ dan $t_{\text {tabel }}=2.00$. Hasil perhitungan $t_{\text {hitung }}>t_{\text {tabel }}$ dapat disimpulkan bahwa hipotesis nol ditolak dan hipotesis alternatif diterima, yang artinya absensi fingerprint mempunyai hubungan yang positif dan signifikan terhadap disiplin kerja karyawan pada PT. Sanbio Laboratories.

4. Kontribusi Pengaruh Absensi Fingerprint Terhadap Disiplin Kerja Karyawan PT. Sanbio Laboratories

Disiplin kerja karyawan PT. Sanbio Laboratories dipengaruhi oleh kontribusi absensi fingerprint sebesar 43,56 persen. Adapun variabel disiplin kerja karyawan juga dipengaruhi oleh faktor-faktor lainnya sebesar 56,44 persen yang dalam penelitian ini tidak dianalisis.

\section{Simpulan}

Berdasarkan deskripsi, analisis hasil penelitian dan pembahasan, dapat ditarik beberapa kesimpulan sebagai berikut:

1. Dari hasil penelitian diketahui bahwa terdapat korelasi antara absensi fingerprint sebagai variabel bebas (X) dengan disiplin kerja karyawan PT. Sanbio Laboratories sebagai variabel terikat $(\mathrm{Y})$ sebesar $\mathrm{R}=0,66$ dengan arah positif (+).

2. Sedangkan Uji Signifikansi Korelasi sebesar $t_{\text {hitung }}=4.94>t_{\text {tabel }}=2.00$, sehingga hipotesis alternatif diterima, yaitu absensi fingerprint mempunyai hubungan yang positif dan signifikan terhadap disiplin kerja karyawan pada PT. Sanbio Laboratories.

\section{Saran}

Berdasarkan kesimpulan di atas dengan mempertimbangkan tujuan penelitian yang ada, maka peneliti mengajukan saran-saran yang diharapkan mendapat perhatian dari pihak terkait khususnya Manajemen PT. Sanbio Laboratories sebagai berikut:

1. Penggunaan teknologi untuk keperluan absensi melalui mesin fingerprint secara tepat akan dapat meningkatkan kedisiplinan kerja para karyawan PT. Sanbio Laboratories yang diharapkan berdampak kepada peningkatan kinerja perusahaan. Dalam hal ini manajemen PT. Sanbio Laboratories harus terus meningkatkan efektivitas penggunaan teknologi absensi tersebut, sehingga sistem absensi yang diterapkan tidak menjadi mubasir/sia-sia.

2. Manajemen PT. Sanbio Laboratories supaya melakukan sosialisasi dan memberikan pemahaman kepada seluruh karyawan PT. Sanbio Laboratories atas manfaat penggunaan mesin absensi fingerprint bagi para karyawannya, serta memberikan garansi atau jaminan keamanan rekam sidik jari secara objektif dan transparan sehingga data kehadiran tidak dapat dimanipulasi.

\section{DAFTAR PUSTAKA}

\section{Buku:}

Arifin, Johar dan A. Fauzi. 2007. Aplikasi Excel dalam Aspek Kuantitatif SDM. Jakarta: Elex Media Komputindo.

Arifin, Johar. 2007. Aplikasi Excel untuk Akuntansi Manajemen Modern. Jakarta: PT. Elex Media Komputindo.

Arikunto, Suharsimi. 2006. Prosedur Penelitian: Suatu Pendekatan Praktik. Jakarta: Rineka Cipta. 
Dodi R. Setiawan \& Yulianti, Pengaruh Absensi Fingerprint Terhadap Disiplin Kerja Karyawan...

Strauss, George and Sayless, Leonard, 2000, Manajemen Personalia Segi Manusia Dalam Organisasi. Terjemahan Grace M. Hadikusuma dan Rochmulyati Hamzah, Jakarta: PT. Pustaka Binaman Pressindi.

Handoko, T Hani. 2001. Manajemen Personalia dan Sumberdaya Manusia,Edisi Kedua. BPFE,Yogyakarta.

Hariandja, Effendi. 2007. Manajemen Sumber Daya Manusia. Jakarta: PT. Grasindo.

Haryadi, Hendi. 2009. Administrasi Perkantoran untuk Manajer dan Staf. Jakarta:Transmedia Pustaka.

Hasibuan, Malayu S. P. 2006, Manajemen Sumber Daya Manusia, Edisi Revisi : Jakarta. Bumi Aksara

Hasibuan, S.P Malayu. 2010. Organisasi dan Motivasi Dasar Peningkatan Produktivitas. Jakarta: Bumi Aksara.

Nursasongko, Edi dan Pulung N. Andono. 2010. Mengenal Dunia Komputer. Jakarta: PT. Elex Media Komputindo.

Sarosa, Samiaji. 2008. Sistem Informasi Akuntansi. Jakarta: Grasindo.

Siagian, Sondang P. 2011. Manajemen Sumber Daya Manusia, Jakarta: PT. Bumi Aksara

Simamora, Henry. 2006. Manajemen Sumber Daya Manusia. Yogyakarta: YPPKN

Sugiyono. 2010. Metode Penelitian Kuantitatif Kualitatif \& RND. Bandung: Alfabeta.

Suprapto, Tommy. 2009. Manajemen. Yogyakarta: MedPress.

Sutrisno, Edy. 2011. Manajemen Sumber Daya Manusia. Jakarta: Kencana

Tofik, Moch. 2010. Panduan Praktis Membuat Aplikasi Penggajian dengan
Microsoft Excel 2007. Jakarta: MediaKita.

Umar, Husein. 2005. Riset Sumber Daya Manusia dalam Organisasi. Jakarta: Gramedia Pustaka Utama.

Suharyanto, Hadriyanu dan Agus Heruanto Hadna. 2005. Manajemen Sumber. Daya Manusia. Cetakan Pertama. Yogyakarta : Media Wacana

\section{Internet:}

https://www.academia.edu/5962949/manual_i nstruction petunjuk_penggunaan_mesin absensi_sidik_jari_solution_fingerprint_1 _solusi_corporindo_teknologi, 2014

https://www.informatika.lipi.go.id/jurnal/impl ementasi-teknologi-biomatic-untuk sitem absensi-perkantoran/Desember 2014.

https://www.absensisidikjari.com/7-langkahpraktis-mudah-menggunakan-absensi, 2014.

http://library.gunadarma.ac.id/repository/view 13784258,2015.

https://www.academia.edu/3252594/Pengaruh Efektivitas_Penerapan_Absensi_Finger_ Print_Terhadap_Disiplin_Pegawai_Negeri Sipil_Di_Sekretariat_Daerah_Kabupaten LLebak, 2015.

http://aresearch.upi.edu/operator/upload/sadp _0704694_chapter3.pdf 